\title{
A PRAGMATIC STUDY OF FIGURATIVE LANGUAGE IN ANONYMOUS MOVIE SCRIPT
}

\author{
By: \\ Ahmad Fauzi Jamaluddin, Maryadi, Siti Zuhriah Ariatmi \\ Muhammadiyah University of Surakarta
}

\begin{abstract}
Abstrak
The research aims at describing the types of figurative language, implicature, and flouting maxim of Anonymous movie. The research employs the descriptive qualitative as the type of the research. The data source of this research is the script of Anonymous movie. Techniques of collecting data are watching the Anonymous movie, searching then downloading the Anonymous movie script, reading the Anonymous movie script, identifying the types of figurative languages in the movie script and underlying them, typing those figurative languages in paper, describing the types of figurative language by using Perrine theory and coding the data. The techniques of data analysis are describing the types of figurative language found in the Anonymous Movie Script, the writer uses Perrine theory (1977), describing the types the implicature, the writer refers to the theory of Grice (1989), and drawing discussion, describing the flouting maxim, the writer uses Cutting's theory (2002). The data are shown with the italic, bold and underline words. One datum analysis presents figurative language, implicature and flouting maxim analysis. So, it doesn't analyze separately. The result of the study shows that 1) the types of figurative language are: Metaphor (30.56\%) which always uses an implicit comparison at the movie's mind. The second position is Hyperbole $(27.78 \%$ ), and the third position is Simile (19.44\%) and the fourth position is Personification $(16.67 \%)$. Based on the frequency of occurrence, Irony $(5.56 \%)$ is in the last position. 2) The all implicature of figurative languages cover conversational implicature $(100 \%)$ and none of them are conventional implicature $(0 \%)$. The conversational implicature divided into: particularized conversational implicature $(94.44 \%)$ and generalized conversational implicature (5.56\%) (3) The flouting maxim are used by the characters: flouting maxim of quality $(86.11 \%)$, flouting maxim of relation $(5.56 \%)$, flouting maxim of manner $(5.56 \%)$, flouting maxim of quantity $(2.78 \%)$.
\end{abstract}

Keywords : figurative language, implicature, maxim violated, Anonymous movie

\section{Introduction}

Figurative language is broadly defined as any way of saying something other than ordinary way (Perrine (1977: 61). According to Warinner (Tarigan, 1985: 179), figurative language is language that is used imaginatively and not literary. It is not intended to be interpreted in a literal sense. Appealing to the imagination, figurative language provides new ways of looking at the new world.

Figurative language can be found in daily communication and literary works, such as poetry, drama, song and movie. In this study, the writer deals with analyzing figurative language in movie script entitled Anonymous written by $\underline{\text { John Orloff and directed by Roland }}$ 
Emmerich. This movie is a fictionalized version of the life of Edward de Vere, 17th Earl of Oxford, an Elizabethancourtier, playwright, poet and patron of the arts. Set within the political atmosphere of the Elizabethan court, the film presents Lord Oxford as the true author of William Shakespeare's plays, and dramatizes events around the succession to Queen Elizabeth I, and the Earl of Essex Rebellion against her. De Vere is depicted as a literary prodigy and the Queen's sometime lover, with whom she has a son, Henry Wriothesley, 3rd Earl of

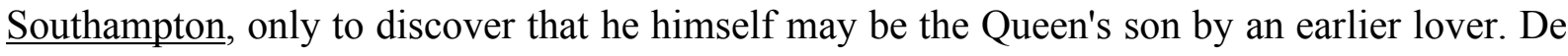
Vere eventually sees his suppressed plays performed through a frontman (Shakespeare), using his production of Richard III to support a rebellion led by his son and $\underline{\text { Robert Devereux, 2nd }}$ Earl of Essex. The insurrection fails, and as a condition for sparing the life of their son, the Queen declares that de Vere will never be known as the author of his plays and poems.

Pragmatic analysis of figurative language in Anonymous movie has done because some of the utterances of Anonymous movie use the figurative language. This paper, therefore, aims to know more deeply the types of figurative language and to understand the implicature of the utterances in that movie. Understanding the content and the speaker's meaning or the implicature of the movie is very important because if the people want to enjoy the movie, the people should understand the implicature of the utterances in that movie.

This study focused on the figurative language in Anonymous movie script. The data are analyzed by using figurative language theory of Perrine (1977), the context speech analysis of Hymes formula (1964), implicature theory of Grice (1975) and flouting maxim theory of Cutting (2002).

\section{Research Method}

This study is descriptive qualitative research, because the writer purposes to identify the types of figurative language, to describe the implicature of figurative language and to describe the maxims violation in the manuscript of Anonymous movie. The data are the sentences containing figurative language found in Anonymous movie. They are 36 data of figurative languages. The data sources are the manuscript of Anonymous movie.

The writer uses documentation and observation as the method of collecting data. The steps that are used for collecting data are as follows: watching the Anonymous movie, searching then downloading the Anonymous movie script, reading the Anonymous movie script, identifying the types of figurative languages in the movie script and underlying them, typing those figurative sentences in paper and coding the data. 
The writer analyzes the data using following steps: categorizing the data into the types of figurative language by using Perrine theory, displaying the data with the context of the data above it, coding the data, describing the types of figurative language found in the Anonymous Movie Script by using Perrine theory, describing the context of speech of the figurative language found in the Anonymous Movie Script by using Hymes formula, describing the types the implicature by referring to the theory of Grice, categorizing into the maxim violaty according to Cutting's Flouting Maxim theory and drawing discussion, conclusion and suggestion based on the data analysis.

\section{Result And Discussion}

This subchapter discusses the writer's analysis of the result and discussion. The results of the analysis are as follow:

\section{The types of Figurative language}

The result of the types of Figurative language as follows:

\begin{tabular}{|r|l|r|r|}
\hline \multirow{2}{*}{ NO } & \multirow{2}{*}{$\begin{array}{c}\text { Types of Figurative } \\
\text { Language }\end{array}$} & \multicolumn{2}{|c|}{ Result(s) } \\
\cline { 3 - 4 } & & $\boldsymbol{\Sigma}$ & \multicolumn{1}{c|}{$\%$} \\
\hline 1 & Metaphor & 11 & $30.56 \%$ \\
\hline 2 & Hyperbole & 10 & $27.78 \%$ \\
\hline 3 & Simile & 7 & $19.44 \%$ \\
\hline 4 & Personification & 6 & $16.67 \%$ \\
\hline 5 & Irony & 2 & $5.56 \%$ \\
\hline & Total & $\mathbf{3 6}$ & $\mathbf{1 0 0 . 0 0 \%}$ \\
\hline
\end{tabular}

Table 1. Figurative Language Types

\section{Implicature}

\section{1/META/ANO/P003/L043}

\section{INT. BROADWAY THEATER - THE STAGE - CONTINUOUS}

((The man with the umbrella stands on the empty stage, a single light on him. He is "PROLOGUE". [We will see the same actor later as the "Prologue" of Henry V])). (("Prologue" continues, as do TITLES)).

(("Prologue" tries to bring the audience to think about who William Shakespeare are)).

PROLOGUE (CONT'D)
: Is it possible Shakespeare owned no books at his death because... he could not read? That he wrote no letters because he, like his father before him and his children after him, could not write? (lets that sink in, then)

Our Shakespeare is a cypher, a ghost; his biography made not by history... but by conjecture. His story not written with facts, but with... imagination. 
The expression of the Prologue, "Our Shakespeare is a cypher. A ghost." above is metaphor because it compares Shakespeare with a cypher and a ghost. It expresses that Shakespeare is a figure that is mysterious person because many people believe that Shakespeare is an illiterate whereas generally that his masterpieces are famous entire the world. So, it raises a big question. From this metaphor description, it is not clear who Shakespeare is, that is why the Prologue states that "Our Shakespeare is a cypher. A ghost." because of Shakespeare is known by his masterpieces, not his life story.

Context : The addressor of the utterance above is Prologue of the story and the addressee is William Shakespeare. The audiences are the people who join in the theater that moment. The topic is to describe William Shakespeare. The relationship among the participants of the event is maintained by speech (channel) and through English language in the form of declarative sentence (code). The message form is shown in the monologue. The event is in the stage of the theater in the morning (setting). The purpose of the event is to explain William Shakespeare life.

Implicature: The utterance “Our Shakespeare is a cipher. A ghost." _means that Prologue tries to describe Shakespeare implicitly as mysterious person. So, it belongs to conversational implicature especially particularized conversational implicature because to get the intention of the speaker, the hearer needs to infer based on a special factors or a specific context. This utterance above flouts the maxim of quality. The meaning of the addressor can be interpreted that he tries to announce that the story of William Shakespeare is still mysterious.

002/SIM/ANO/P-005/L-21

\section{THROUGH THE CRACKS OF THE STAGE'S FLOORBOARDS}

((--the soldiers jump onto the stage and spread out, Pole amongst them.

They search the manuscript of Edward de Vere under Robert Cecil's order.

The scripts are believed will bring the badness to the Kingdom)).

((Ben Jonson is hiding under the stage when Pole and his soldier come)).

POLE : Out with you! Jonson! We'll smoke you out like a rat

(CONT'D) if we have to!

(beat)

Jonson?! Jonson!!

((Ben Jonson is trying to hide the manuscripts under the stage)).

The simile expression is the comparison between two different things. In this case, Pole states that Jonson is equated with a rat. Generally, a rat is a rodent, living in a pit and it is annoying for everyone. Here, Pole does it because Jonson is annoying people not only by his 
play but also his attitude because in that time, he brings some Edward's manuscripts. These manuscripts are believed as the plays who confront the citizen to depose Robert Cecil. So, Robert Cecil gives the order to Pole to catch Benjamin Jonson.

The simile expression in this data, "I'll smoke you out like a rat!" has a meaning that Pole describes Jonson as an annoying people, like a rat.

Context: The addressor of the utterance above is Pole and the addressee is Ben Jonson. The audiences are the people who are near him that moment. The topic is concerned with Ben Jonson's arresting. The relationship among the participants of the event is maintained by speech (channel) and through English language in the form of declarative sentence (code). The message form is shown in the dialogue. The event is carried out in the Stage's Floorboards at the night (setting). The purpose of the event is to arrest Ben Jonson.

Implicature: By the explanation above, Pole implicitly gives an order to Ben Jonson to go out from his hiding otherwise he will burn the stage. It is a threatening utterance. It is included to conversational implicature especially generalized conversational implicature because to get the intention of the speaker, the hearer doesn't need to infer based on specific context. Rat is a symbol of slicer so it clearly enough that Ben Jonson is a person that was annoyed Pole. This utterance also flouts the maxim of quality. The meaning of the addressor can be interpreted that he is so angry with the addressee until he wants to burn the addressee to make him out from his hiding.

012/HYP/ANO/P045/L038

INT. CECIL HOUSE - GREAT HALL - DAY

(Thirty years earlier).

((William Cecil is standing in front of an enormous fireplace, pacing in a pique of anger)).

((William Cecil SLAMS his fists on a table. He gets angry because Young Oxford has broken the rule of his house. Young Oxford has been writing a poem and play behind him)).

((William Cecil is a faithful Christ and he believes that writing a poem and play is a $\sin )$ ).

$\begin{array}{ll}\text { WILLIAM } & : \begin{array}{l}\text { Enough! Thou shalt not worship false idols in my } \\ \text { household! Your everlasting soul hangs in the } \\ \text { beCIL }\end{array} \\ \text { balance. Not poems. Your soul! } \\ \text { YOUNG } \\ \text { OXFORD }\end{array}$

((William Cecil turns away in frustration as much as disgust)). 
Young Oxford's say above uses excessive words. The utterance means that poem is the addressor's hobby. By the use of excessive words, it fulfills the hyperbole Perrine's theory.

Context: The addressor of the utterance above is Young Oxford and the addressee is William Cecil. The audience is William Cecil. The topic is Young Oxford debates with William Cecil. The relationship among the participants of the event is maintained by speech (channel) and through English language in the form of declarative sentence (code). The message form is shown in the dialogue. The event is carried out in the Great Hall of Cecil house at the day (setting). The purpose of the event is to maintain his principle and to make William Cecil understand.

Implicature: The utterance "My poems are my soul!" has an implicit meaning that writing poem is his hobby and he can't let it go. Moreover, it is included to conversational implicature especially particularized conversational implicature because to get the intention of the speaker, the hearer needs to infer based on specific context. This utterance also flouts the maxim of quality. The meaning of the addressor can be interpreted that he loves writing the poems and he doesn't want to stop it.

014/PERS/ANO/P048/L024-025

INT. THE ROSE THEATER - DAY

((Thirty-two years later)).

((ON STAGE))

((An actor, CONDELL (40's), dressed all in white (even his face is painted white) enters stage. He is "Prologue" of the play entitles "Henry V")).

((He addresses the audience directly)).

((The situation is same with the data 013/SIM/ANO/P048/L021-023

because it's one scene)).

"PROLOGUE" : : Oh, for a muse of fire, that would ascend the brightest heaven of invention. A kingdom for a stage, princes to act, and monarchs to behold the swelling scene! Then should warlike Harry, like himself, assume the port of Mars, and at his heels should famine, sword, and fire crouch for his employment. Can this cockpit hold the vasty fields of France?

The utterance "and fire crouch for his employment." is personification. Therefore, "fire" in the statement above is "crouching". So, it is included Perrine's personification theory because "fire" is doing like human being. The utterance above means that because of the spirit of Harry who is like god of war making everyone even everything crouch to him. 
Context: The addressor of the utterance above is Prologue of a play entitled "Henry V" and the addressee is the audiences. The audiences are the people who watched the play that moment. The topic is concerned with the story of Henry V that burn England citizen's spirit to fight for freedom against France. The relationship among the participants of the event is maintained by speech (channel) and through English language in the form of declarative sentence (code). The message form is shown in the monologue. The event is carried out in the Rose Theater at the day (setting). The purpose of the event is to explain Henry $\mathrm{V}$ struggle.

Implicature: The utterance "and fire crouch for his employment" has a meaning that because of the spirit of Harry who is like god of war make everyone even everything crouch to him. So, it is included to conversational implicature especially particularized conversational implicature because to get the intention of the speaker, the hearer needs to infer based on specific context. This utterance also flouts the maxim of quality. The meaning of the addressor can be interpreted that he tries to describe Harry as a powerful person that can lead the people to the victory.

\section{7/IRON/ANO/P086/L048-049 INT. OXFORD STONE - STUDY - DUSK}

((Shakespeare meets Oxford to ask more money. He warns Oxford that he will announce the truth to the public about the true author of the play performed under his name if he doesn't get what he wants)).

((Then, Oxford gives him the money)).

((Oxford watches Shakespeare walk down the road through a Window)).

FRANCESCO : Forgive me for speaking of things above my place or understanding, signor. But... Is this wise? They have already tried to kill you once.

OXFORD : Wisdom, Francesco, is a quality I have unfortunately never possessed...

((Francesco stares at Oxford who is deep in thought)).

((The sound of heated love making takes us to...))

The sentences "Wisdom, Francesco, is a quality I have unfortunately never possessed..." is irony. It creates an ironical sentence. The phrases "is quality I have" and “unfortunately never possessed" are contradictive. The sentence has a meaning that Oxford who writes the manuscript of a greatest play such as Macbeth, Hamlet, Romeo and Juliet, etc 
is never exposed because gentry can't write a verse even a play. He makes someone to perform his play under that man. And he gets nothing. So, it is irony.

Context: The addressor of the utterance above is Oxford and the addressee is Francesco. The audience is Francesco. The topic is Oxford thought that what he has had was not really he possessed. The relationship among the participants of the event is maintained by speech (channel) and through English language in the form of declarative sentence (code). The message form is shown in the dialogue. The event is carried out in the study room of Oxford's abode at the dusk (setting). The purpose of the event is to describe Oxford's fate as an unknown composer although his works is famous.

Implicature:The utterance "Wisdom, Francesco, is a quality I have unfortunately never possessed..." has a meaning that Oxford who writes the manuscript of a greatest play such as Macbeth, Hamlet, Romeo and Juliet, etc is never exposed because gentry can't write a verse even a play. He makes someone to perform his play under that man. And he gets nothing. Moreover, it is included to conversational implicature especially particularized conversational implicature because to get the intention of the speaker, the hearer needs to infer based on specific context. This utterance also flouts the maxim of quality. The meaning of the addressor can be interpreted that he has a good skill on writing poems and plays but he can show it because he is nobleman and the nobleman can't do that in that era. So, he only can make someone to play them under the other man's name.

The data implicature used in figurative language types:

Table 2 Implicature of Figurative Language

\begin{tabular}{|c|l|r|r|}
\hline \multirow{2}{*}{ NO } & \multirow{2}{*}{ Implicature Types } & \multicolumn{2}{|c|}{ Result(s) } \\
\cline { 3 - 4 } & & $\boldsymbol{\Sigma}$ & \multicolumn{1}{c|}{$\%$} \\
\hline 1 & Conversational Implicature & 36 & $100.00 \%$ \\
\hline 2 & Conventional Implicature & 0 & $0 \%$ \\
\hline & Total & $\mathbf{3 6}$ & $\mathbf{1 0 0 . 0 0 \%}$ \\
\hline
\end{tabular}

The data of conversational implicature used in figurative language types:

Table 3 Conversational Implicature

\begin{tabular}{|c|l|r|r|}
\hline \multirow{2}{*}{ NO } & \multicolumn{2}{|c|}{ Conversational Implicature } & \multicolumn{2}{|c|}{ Result(s) } \\
\cline { 3 - 4 } & & $\boldsymbol{\Sigma}$ & \multicolumn{1}{c|}{$\%$} \\
\hline 1 & Generalized Conversational Implicature & 2 & $5.56 \%$ \\
\hline 2 & Particularized Conversational Implicature & 34 & $94.44 \%$ \\
\hline & Total & $\mathbf{3 6}$ & $\mathbf{1 0 0 . 0 0 \%}$ \\
\hline
\end{tabular}




\section{Maxim Violation}

The writer found some maxim violations in the data, they are:

\begin{tabular}{|l|l|r|r|}
\hline \multirow{2}{*}{ NO } & \multirow{2}{*}{ Flouting Maxim } & \multicolumn{2}{|c|}{ Result(s) } \\
\cline { 3 - 4 } & & $\boldsymbol{\Sigma}$ & \multicolumn{1}{c|}{$\%$} \\
\hline 1 & Quality & 31 & $86.11 \%$ \\
\hline 2 & Relation & 2 & $5.56 \%$ \\
\hline 3 & Manner & 2 & $5.56 \%$ \\
\hline 4 & Quantity & 1 & $2.78 \%$ \\
\hline & Total & $\mathbf{3 6}$ & $\mathbf{1 0 0 . 0 0 \%}$ \\
\hline
\end{tabular}

Table 4. Flouting Maxim

\section{Conclusion}

Based on the data analysis and the discussion the writer gets the following conclusions:

1. The researcher takes Perrine's theory and other scientists to find out kind of figurative language in the poems. After the researcher takes the data and classifies them based on their categories of figurative language, he concludes that the Anonymous movie script uses some figurative language types. They are: firstly is Metaphor (30.56\%) which always uses an implicit comparison at the movie's mind. The second position is Hyperbole (27.78\%), and the third position is Simile (19.44\%) and the fourth position is Personification (16.67\%). Based on the frequency of occurrence, Irony $(5.56 \%)$ is in the last position. The figurative language in Anonymous movie script always uses an implicit comparison at the movie's mind.

2. The implicature of figurative language in Anonymous movie script, the researcher finds some information about it. All of the figurative languages in the Anonymous movie script are conversational implicature: particularized conversational implicature (94.44\%) and generalized conversational implicature $(5.56 \%)$ and the writer also found the violating of the maxim as follows: flouting maxim of quality $(86.11 \%)$, flouting maxim of relation (5.56\%), flouting maxim of manner (5.56\%), flouting maxim of quantity $(2.78 \%)$.

\section{References}

Abrams, M, H. 1971. Glossary of Literature Term. New York: Holt, Rinehart and Winson, Inc.

Baker, M. 1996. In Other Words. A Course Book on Translation. London: Routledge.

Black, E. 2006. Pragmatic Stylistics. Edinburgh: Edinburgh University Press.

Brown, G. and Yule, G. 1983. Discourse Analysis. Cambridge: Cambridge University. 
Cutting, Joan. 2002. Pragmatics and Discourse: A Resource Book for Students. London: Routledge

Crystal, David. 1997. The Cambridge Encyclopedia of Language. New York: Cambridge University Press.

Dian. 2005. A Pragmatic Analysis on Figurative Language in English Translation of Bukhori Hadith. Unpublished Research Paper. Surakarta: Muhammadiyah University of Surakarta

Fadilah, Azir. 2004. An Analysis on Figurative Language used in Stephen Crane's The Red Badge of Courage. Unpublished Research Paper. Surakarta: Muhammadiyah University of Surakarta.

Grice, H.P. 1989. Studies in the Way of Words. USA: Harvard University Press.

Grundy. P. 2000. Doing Pragmatics. London: Edward Arnold.

Hatch. E. 1992. Discourse And Language Education. Cambridge: Cambridge University Press.

Ktweaver. 2013. Film Genres. (online) Available from URL http://www.slideshare. net/ktweaver/film-genres-26987794 accessed on Saturday March 14th, 2015 on 4.22 PM

Leech, Geoffrey. 1983. The Principle of Pragmatics. London: Longman Group Limited.

Levinson, S.C. 1983. Pragmatics: An Introduction. Cambrige: Cambrige University Press.

Issac, S, and Michael, W. B. 1987. Handbook in Research and Evaluation for Education and Behavioral Sciences. San Diego: Edits Publishers.

Moleong, L. J. 2001. Metodologi Penelitian Kualitatif. Bandung: Remadja Posdakarya.

Nugroho, A. P. 2013. Pengertian Film. (online) Available from URL https://adhitoge.wordpress.com/2013/09/01/pengertian-film/ accessed on accessed on Monday, March 30th, 2015 02.25 PM

Nunan, D. 1993. Introducing Discourse Analysis. London: Penguin Books.

Orloff, John. 2011. Anonymous. (Online) Avalilabe from URL www.imsdb.com/scripts/Anonymous.html accessed on Tuesday, January 27th, 2015 7:36 $\mathrm{AM}$

Peccei, J. S. 1999. Pragmatics Language Workbooks. London and New York: Taylor and Francis Routledge

Perrine, Laurence. 1983. Literature: Structure, Sound, and Sense. New York:Harcourt Brace Javanovich, Inc.

Pradopo, Rachmat Djoko. 2003. Metodologi Penelitian Sastra. Yogyakarta: Hanindita 
Rendy, J. P, Stevanus. 2013. Translation Analysis on Figurative Language in The Oldman And The Sea by Ernest Hemingway into Lelaki Tua Dan Laut by Sapardi Djoko Damon. Semarang: Dian Nuswantoro University. Avalilabe from URL http://eprints.dinus.ac.id/8162/1/jurnal_11686.pdf accessed on Monday, February 2nd, $20156.05 \mathrm{pm}$

Rodman, George. 2009. Media in a Charging World. Second Edition. New York: McGrawHill.

Saputri, E. E. W and Setyaningsih, N. 2014. An Analysis of Figurative Languages Used in Rick Riordan's Novel Entitled "The Heroes Of Olympics, Book Three: The Mark Of Athena". Semarang: Dian Nuswantoro University. Avalilabe from URL http://eprints.dinus.ac.id/8285/1/jurnal_13480.pdf accessed on Monday, February 2nd, $20155.58 \mathrm{PM}$

Saputri, W. E. 2011. A Pragmatics Analysis of Figurative Language Used in Revelation Bible in New Testement. Unpublished Research Paper. Surakarta: Muhammadiyah University of Surakarta

Sherrin, N. 1995. The Oxford Dictionary of Humorous Quotations. Oxford: Oxford University Press.

Siswantoro. 2005. Apresiasi Sastra Inggris. Surakarta: Muhammadiyah UniversityPress.

Suryani, A. T. 2013. An Analysis of Wole Soyinka's Poems: Figurative Language Cases. Jombang: STKIP PGRI of Jombang. Available from URL http://www.google.co.id/url?sa=t\&rct=j\&q=\&esrc=s\&source=web\&cd=1\&ved=0CBsQ FjAAahUKEwitude2e_GAhWELpQKHf_5DBI\&url=http\%3A\%2F\%2Fejurnal.stkipjb. ac.id\%2Findex.php\%2FAS\%2Farticle $\% 2$ Fdownload\%2F $223 \% 2 \mathrm{~F} 159 \&$ ei $=2 \mathrm{C} 6 \mathrm{wVa3tO}$ YTd0AT_87OQAQ\&usg=AFQjCNEgNW2NST0UNhVoD09fPemTvCbyPg\&sig2=OK xmiDkGpcBw5eeTPT1XYg accessed on Wednesday, April 22nd, 2015 11.26 AM

Tarigan, H.G. 1985. Pengajaran Gaya Bahasa. Jakarta: PT. Angkasa

Tirajoh, Juliana. 1988. English Poetry: An Introduction to Indonesian Students. Jakarta: Depdikbud

Yule, George. 1996. Pragmatics. Oxford: Oxford University Press.

Yuri, A. Ratna and Rosa, R. N. 2013. An Analysis of Types of Figurative Language Used in Internet Advertisements. Padang: Padang State University Available from URL http://download.portalgaruda.org/article.php?article $=101075 \& \mathrm{val}=1508$ accessed on Wednesday, April 22nd, 2015 11.07AM 